2019 TheoLogica

An International Journal for Philosophy of Religion and Philosophical Theology

S. I. THE SON OF GOD

DOI: https://doi.org/10.14428/thl.v3i1.2323

\title{
Christ, the Power and Possibility of God in St. Anselm of Canterbury
}

JONATHAN S. MCINTOSH

New Saint Andrews College

jmcintosh@nsa.edu

\begin{abstract}
In this article I examine the modal theism of St. Anselm of Canterbury, arguing that the person of the divine Son plays an important role in how Anselm thinks about God's power and possibilities. Beginning with his first major theological work, the Monologion, I show how Anselm's characterizes God's knowledge of creation, not in the traditional, Augustinian terms of an intellectual divine "idea," but in the comparatively more linguistic terms of a divine "locutio" or "utterance." I go on to argue that this sets Anselm up for a somewhat unique modal theology, one in which God is best understood as acting and creating, not against the backdrop of an already defined and existing domain of possibilities, but in a way that makes him the inventor and creator of his own possibilities. In the second part of the article, I turn to Anselm's influential work of Christology, Cur Deus Homo, to examine how his "theistic actualism" is paralleled in select aspects of his account of the divine Son's Incarnation in the person and work of Jesus Christ.
\end{abstract}

Keywords: Anselm, Christology, Modality, Omnipotence, Monologion, Cur Deus Homo

In his first letter to the church in Corinth, the Apostle Paul describes Jesus Christ, the Incarnate divine Son, as the very "wisdom" (sophia) and "power" (dynamis) of God (1 Cor. 1:24). Yet despite this authoritative identification, together with the enormous influence the doctrine of the divine Son has exercised within Christian thought historically, a systematic philosophical account of what it means for Christ to be the very power and possibility of God has arguably yet to be written. In this article my purpose is to commend, as one particularly important and noteworthy resource for the development of a properly Christocentric modal theology, the writings of the late eleventh- and early twelfth-century theologian and philosopher, St. Anselm of Canterbury (1033-1109). Beginning with his first major 
theological work, the Monologion, I show how Anselm characterizes God's knowledge of creation in and through the divine Son, not in the traditional, Augustinian terms of an intellectual divine "idea," but with the more linguistic metaphor of a divine "locutio" or "utterance." This shift, I argue, sets Anselm up for a somewhat unique, even if largely implicit modal theology. For Anselm, as I interpret him, God is best understood as acting and creating, not against the backdrop of an already defined and hence divinely conceived domain of possibilities, but in such a way as to make him the inventor and creator of his own possibilities. On this alternative, "theistic actualist" reading of Anselm, it is what God actually does and creates, in and through the divine Son, that is responsible for determining and defining all that is possible for God to do. With this general, modal theology in place, in the second part of the article I turn to Anselm's famous and influential work of Christology and soteriology, Cur Deus Homo, to consider how his theistic actualism is paralleled in his account of the divine Son's Incarnation in the person and work of Jesus Christ. As I hope to show throughout this study, in Anselm we meet with a unique yet cogent account of what it might mean for Christ to be the very "wisdom and power of God."

Our study of Anselm's Christological modality begins with his first major theological work, the Monologion. ${ }^{1}$ The precursor to his more well-known Proslogion containing his so-called "ontological" argument for God's existence, the Monologion attempts to demonstrate by "reason alone" - sola ratione - the Christian doctrine of God. After proving, first, God's existence (chs. 1-4); second, his aseity or self-existence (chs. 5-6); and third, the existence of everything else through God yet from nothing (chs. 7-8), Anselm turns in the ninth chapter to address the respect in which things might nevertheless be said to have pre-existed in God prior to his creating them. In an echo of St. Augustine's famous doctrine of the divine ideas, Anselm declares that "by no means can anything reasonably be made by anyone unless beforehand there is in the maker's reason a certain pattern (exemplum), as it were, of the thing to be made-or more fittingly put, a form (forma) or likeness (similitudo) or rule (regula)" (ch. 9). ${ }^{2}$ Yet of all the terms Anselm uses to describe creation's pre-existence in God, significantly, the one word he omits to use is the characteristically Augustinian word idea itself (Evans 1978, 27, note 2). Instead, Anselm substitutes it for a concept more to his own liking: the

\footnotetext{
${ }^{1}$ For an expanded version of the following study of Anselm's Monologion in the first part of this article, see McIntosh (2017b). The following distillation is here provided with permission of, and thanks to, the publisher.

${ }^{2}$ All translations are from Jasper Hopkins and Herbert Richardson's translation (Anselm 2000). All Latin quotations are from the critical edition of Anselm's Opera Omnia (Anselm 1946).
} 
Anselmian doctrine of the divine locutio, or "utterance." As Anselm rhetorically asks and answers, "But what is this form of things which in the Maker's reason preceded the things to be created, other than an expression-of-things (locutio rerum) in the Maker's reason? - just as when a craftsman who is about to make a work from his craft first speaks of it within himself by a mental conception?" (ch. 10). ${ }^{3}$ On Anselm's initial yet, as we shall see, definitive characterization of God's knowledge of creation and its possibilities - a knowledge he will later in the Monologion identify with the divine Son himself-the way in which creation preexists in, and hence is made possible by, God is not as a host of divine ideas or mental acts, but as a single divine locutio or speech act. ${ }^{4}$

While there are a number of important implications of Anselm's shift from a more intellectual to a more linguistic metaphor for God's knowledge of and relationship to creation, of primary interest to us here is the significance it holds for how Anselm would have us understand the nature and scope of those divine possibilities contained and spoken in God's creative locutio. One dimension to the Augustinian metaphor of the divine "ideas," after all, is the way it has historically tended to encourage the view that God's creative activity or speech is at least conceptually or logically, if not also ontologically, preceded and so made possible by a prior and comparatively passive act of speculative knowing. God first thinks his ideas, in short, and only afterwards acts on them. Insofar as God's ideas, moreover, have likewise tended to be understood as providing a register or roster of "all the ways" in which God's infinite essence might be "imitated" or "participated in" by his possible, finite creatures, the divine ideas tradition has further implied that there must therefore be in God an infinite and unrealized surplus of ideas of possible creatures that are known prior to and independently of those specific possibilities he chooses to actually realize or instantiate within creation. ${ }^{5}$ What God actually does or makes is merely a subset of that infinite yet iterated domain all the possible things that he could do or make.

3 "Illa autem rerum forma, quae in eius ratione res creandas praecedebat: quid aliud est quam rerum quaedam in ipsa ratione locutio, veluti cum faber facturus aliquod suae artis opus prius illud intra se dicit mentis conceptione?".

4 As Arjo Vanderjagt comments on this chapter, "Speech lies at the very basis of Anselm's thought. This much is immediately clear, for example, from the famous chapter 10 of the Monologion. Here Anselm discusses God's act of creation of the universe in terms of language" (Vanderjagt 1999, 726).

${ }^{5}$ Augustine himself, for example, implies the existence of an unused surplus of divine possibility in City of God 12.19, where he, in Simo Knuuttila's summary, "criticizes the ancient doctrines which claimed that the only permissible notion of infinity is the infinite in potentia. According to him, an infinite series of numbers exist actually in God's thought, and God could create an infinite number of individuals of a species and know each of them simultaneously" 
In contrast with this "theistic possibilism," as we might term it, of the Augustinian divine ideas tradition, defined here as the view that God's possibilities for creation exist and are defined prior to and independent of what he actually makes, is the very different modal theism implied by Anselm's doctrine of the divine locutio. The first hint of this difference we get is Anselm's statement that "before all things were made there was in the Supreme Nature's reason what they were going to be or what kind they were going to be or how they were going to be (quid aut qualia aut quomodo futura essent)" (ch. 9), but in which no mention is made of those putatively possible creatures which are never going to be. A little later Anselm emphasizes the exclusive actuality or futurity of the objects spoken in the divine locutio when he again describes the latter in terms of a "viewing mentally, with the acute gaze of thought, the things themselves which already exist or are going to exist (res ipsae vel futurae vel iam existentes)" (ch. 10). The divine locutio includes only what is or what will be, again, with no mention made of those merely possible things or creatures which allegedly could but never will be. And at the end of the same chapter, Anselm stresses once more the intentional, actualist character of the divine locutio when (surprisingly, given his emphasis earlier in the Monologion on the divine aseity) he almost goes so far as to imply that the divine locutio exists for the sake of the reality of the very creatures spoken by it: "such an Expression of objects can justifiably be seen to have existed before these objects, in order that they might be made through it (talem rerum locutionem et fuisse antequam essent ut per eam fierent)." What God speaks in the divine locutio, at least with respect to creation and its possibilities, he speaks for the sake of the world and its creatures that he actually makes, and nothing more, for as Anselm will give us reason to understand later in the Monologion, apart from those things which God has actually spoken, together with their possibilities, there simply is nothing "more" to be said.

If so, one might begin to wonder at this point what Anselm's understanding would be, then, of those supposedly possible but unrealized things or worlds that we are capable of imagining or conceiving God as being able, in his omnipotence, to do or make. Although Anselm doesn't address this question directly, he provides an at least indirect answer when he contrasts the locutio of the divine craftsman, on the one hand, with that of the artistic locutio of the human craftsman on the other. Whereas God in his aseity depends upon nothing but his own self for

(Knuuttila 1993, 69). Another example is Augustine's gloss on Genesis 19:22, when the Angel of the Lord tells Lot that he "can do nothing" to destroy Sodom and Gomorrah until Lot arrives safely in the city of Zoar, which Augustine interprets as a statement about what the Lord "could do through his power, but not through his justice" (poterat per potentiam, sed non poterat per iustitiam). Augustine, Contra Gaudentium 1.30.35, cited in Courtenay $(1990,29)$. 
the expression of the things that he makes, the human craftsman, by comparison, "cannot at all conceive in his mind, imaginatively, any material object except one which he has already in some way experienced (either in its entirety all at once or through parts from various objects)" (ch. 11). ${ }^{6}$ The human craftsman's imagination and art, in other words, are only possible because of the actual, created forms he discovers in the world around him. And while Anselm's point here is merely to highlight the radical limits of human imagination and conceivability and their dependence upon those things that have actually been made, his point would nevertheless seem to have an important application to the question of our ability to imagine any unrealized possibilities, including those supposedly possible for God. As Anselm continues in the same place, "although a man can form the concept or the image of some kind of animal which nowhere exists, he can do so only by therein putting together parts which he has drawn into his memory from objects previously experienced." If so, then all our concepts even for those "things" which God has not in fact done or made, accordingly, would seem to fall into the category of a kind of artistic locutio that is entirely drawn from, and so depends upon, our experience of those things which God has actually done or made. On such an account, fictional creatures such as unicorns, for example, would not be known, even by God, as distinct, possible creatures with their own determinate essence or form, but as Katherin Rogers has summarized Anselm's view in a different context, they would be known by God simply "as what they are, the fictive objects of created thought. And it is He who is causing the relevant creatures, thoughts, properties etc. which produce and constitute the unicorns" (Rogers 2009, 328). ${ }^{8}$ For Anselm, in sum, what we take to be possible for God is a consequence of, and is dependent upon, what God has already made actual.

6 "Illa namque nihil omnino aliunde assumpsit, unde vel eorum quae factura erat formam in seipsa compingeret, vel ea ipsa hoc quod sunt perficeret. Faber vero penitus nec mente potest aliquid corporeum imaginando concipere, nisi id quod aut totum simul aut per partes ex aliquibus rebus aliquomodo iam didicit."

7 "Quanquam enim homo tale aliquod animal possit cogitando vel pingendo quale nusquam sit confingere: nequaquam tamen hoc facere valet, nisi componendo in eo partes, quas ex rebus alias cognitis in memoriam attraxit."

${ }^{8}$ Tetsuro Shimizu makes a related claim when he says that, for Anselm, the human locutiowhich may now be seen to include the locutio for any imaginary, non-existing thing - is a "likeness of an existing thing" and so "an imitation of the imitation of God's speaking as the first and principal essentia" (Shimizu 2006, 181). In reference to Thomas Aquinas's doctrine of the Verbum, Mark Jordan makes the observation that creatures are God's "Word's words" (Jordan 1984, 31). If so, then in keeping with this we might characterize Anselm's view of unrealized, counterfactual possibilities conceived by us, not as God's possible but unrealized words, but as God's "Word's words' words." 
The utter dependence of all our ideas for what is possible on what actually exists isn't the only place in which Anselm contrasts our thinking about possibilities and God's. Later in the Monologion, in another, equally suggestive juxtaposition, Anselm writes how, "unlike a man," in which there is a real distinction and interval between our ideas and our actions based on those ideas, "the Supreme Spirit never fails to express what it understands" (Nam non ut homo non semper dicit quod intelligit-ch. 29). What God knows, in short, is identical with what God speaks. But if so, then his knowledge of what is possible is likewise entirely bound up with, and in a sense even contained within, those things he actually, creatively speaks. ${ }^{9}$ Significantly, it is only at this point, having so firmly identified God's understanding with his speaking, that Anselm also identifies, at last, the divine locutio with the divine Word (Verbum) of God revealed in Scripture and confessed by the Church (ch. 30). This identity of the divine speaking and knowing locutio as the divine Word, moreover, leads Anselm to yet another statement bearing on the question of God's possibilities. For "[w]ithout doubt," he declares, "every word is a word of some thing; indeed, if there never existed a creature, then there would exist no word of a creature... For there can be no word (or image) of that which neither did exist, does exist, nor will exist" (ch. 32). ${ }^{10}$ The divine locutio, in which God speaks not only everything that he makes, but also everything that he knows, is also the divine Word. But words, as Anselm indicates here, are inherently intentional in nature, being about and implicating the reality and actuality of the things they signify. From this vantage point Anselm's earlier failure to include

\footnotetext{
${ }^{9}$ Thus, I would differ somewhat from Knuuttila when, in his reading of the locutio in terms of Augustine's ideas, he writes that, for Anselm, the divine Word involves an "explication of ... all things which can imitate" the divine being, and that "he believed, like Augustine, that God's thought ... models things which are not actualized" (Knuuttila 2004, 119-20). The only evidence Knuuttila cites for these claims is Anselm's admission in On Freedom of Choice 2 that "Adam or the Devil could have not sinned" and his statement in On the Virgin Conception 18 that "the Son of God could have been begotten from another mother, though it was fitting that he was a son of the Virgin" (2004, 129, note 30). Both of these examples, however, are cases of unrealized possible actions of already existing beings, the reality of which Anselm does not deny; what neither of these cases represent are instances of possible kinds or individuals which God allegedly could have created but didn't. I think Dániel Deme, by contrast, hits nearer the mark when, in a comment made in regard to the Monologion as a whole, he says that Anselm "emphasises that what God knows, what is in his 'mind', necessarily is. The one who is so truly that he cannot be thought as nonexistent thinks so truly that what he thinks cannot be non-existent either. God wills what he knows, so it is impossible for him to know something that is not his own, something alien from him. An introduction of something, that is not God's own in his own universe is an attempt to create a fatal dualism, which threatens his sovereignty" (Deme 2003, 52).

10 "Nempe omne verbum alicuius rei verbum est. Denique, si numquam creatura esset, nullum eius esset verbum... Eius enim quod nec fuit nec est nec futurum est, nullum verbum esse potest."
} 
God's merely possible creatures within the divine locutio begins to look especially deliberate, for God's locutio just is his Word, and according to Anselm's linguistic ontology, God has and can have no word for those "things" he never actually intends to creatively speak.

If the divine Word, however, includes only what God actually creates and nothing at all of what he never creates, does this mean (and as some readers have interpreted him) that the world God has actually created is also the only world God could have made, or that it was perhaps even necessary that God should create it? ${ }^{11}$ Anselm's answer to these questions is "no." Even if God had not created anything-a hypothesis that Anselm does not argue for but simply takes for granted-Anselm suggests that, in this event, God simply would not have had a word for any creature. Nonetheless, Anselm assures us, were that the case God still would have eternally known and hence would have had an eternal Word for himself (since for Anselm one cannot know something without having a word for it). ${ }^{12}$ As he concludes chapter 32, "Consequently, whether this Spirit be thought of as not having any creatures or whether it be thought of as having creatures, its coeternal Word must be with it." The implication therefore seems to be that whatever God does or purposes to do is contained in his divine Word, such that had God determined to create nothing, then no creation, and hence no creational possibilities, would have been contained in that Word; alternatively, had God wanted to create a different world or different things than he did, such a scenario wouldn't have involved him actualizing other possible worlds or things presumed to be existing in the divine locutio; rather, in his locutio God would simply have had to have fashioned or devised those differing possibilities from the outset and in the

${ }^{11}$ Katherin Rogers, for example, interprets Anselm along such necessitarian lines when she attributes to him the view that God not only "could not have failed to create," but what is more, that he "'had to' create the very world which He has actually created" (Rogers 1997, 55-6). See also Rogers (2003, 1-8; 2008, 192-205). Likewise, William Courtenay has interpreted Anselm as saying that "God does not have the ability to will that which he has not willed" (Courtenay 1975, 62). Finally, Sandra Visser and Thomas Williams, while they do not view Anselm as intending to limit what God can do to what he actually does, nevertheless see his denial of the reality of non-existing possibilities as making it "difficult for Anselm to say unambiguously whether God could have created otherwise than he actually did... The mere fact (if it is a fact) that there are unrealized possibilities... at least opens up the conceptual space necessary to pose the question [of God's freedom to create otherwise] in the first place. If we cannot say for certain that there are unrealized possibilities, we certainly cannot say determinately whether God could have actualized some of them" (Visser and Williams 2009, 130-31).

${ }^{12}$ As William Mann thus observes, "In the absence of a created world there would be no created world for God to understand. Even so, [a] supremely wise God would be aware of and understand something, namely, Himself" (Mann 2004, 266). 
first place. If so, then the picture that thus emerges is one in which God might have created or acted differently or otherwise than he did, but that in order to do so, more than merely actualizing a different set of already existing possibilities, God would instead have had to first speak, through the divine locutio, a different set of possibilities into existence for him to realize. Among Anselm scholars, Brian Leftow has perhaps gone the furthest in attributing this view to Anselm, albeit in a completely different context, when he says that, for Anselm, "all possible states of affairs are possible due only to God's creative act... [T] here are such things as possible alternatives to God's action only subsequent to its taking place. Can it be true that God can do other than He does, as He acts, if the possibility of alternative actions exists only logically after He acts? Only if the truth of this claim does not involve the existence of possible states of affairs such that alternate actions of God would realize some of them" (Leftow 1995, 172-3, note 30). ${ }^{13}$ Again, the divine Word-qua-locutio contains only those determinate realities, along with their possibilities, which God freely purposes to create, and nothing more, for apart from those things and relations whose content is creatively intended and spoken in the divine locutio, as was said before, there simply is nothing "more" to be had. ${ }^{14}$

${ }^{13}$ Brian Leftow makes this comment in regard, not to Anselm's Monologion, but to his argument for the necessity of the Incarnation in Cur Deus Homo. For Leftow's own, more recent theistic actualist account of God as the creator of his own modal truths, see Leftow (2012, 272-98). This interpretation of Anselm might also be compared with the "voluntarism" defended by James Ross and in his related interpretation of Aquinas. As Ross puts it, "God's power is more awesome. Its domain is realized with its exercise. What is possible ad extra is a result of what God does. God's power has no exemplar objects, only a perimeter (that is, finite being) plus a limit (that of internal consistency, compatibility with the divine being). God creates the kinds, the natures of things, along with things. And he settles what-might-have-been insofar as it is a consequence of what exists (...) Thus, there is no mere possibility with content... [T] here are only descriptions, actual and potential, that might, for all we know so far, have been satisfied. They do not, however, "pick out" any definite content that, if actual, would satisfy them. All content ad extra is caused by God. In sum, God creates the possibility, impossibility, and counterfactuality that has content (real situations) involving being other than God" (Ross 1986, 318-19). For Ross's interpretation of Aquinas along these lines, see Ross (1990).

${ }^{14}$ As Anselm will argue in his later dialogue On the Fall of the Devil, ch. 12-in response to the claim that before and independent of things eventually coming to be, they must have already had the possibility of existing - "what is nothing has nothing at all and hence has no ability, and without any ability is altogether unable." Anselm's near contemporary, Peter Damian (1007-1072), had wryly observed in his famous letter On Divine Omnipotence that God, for all his power (or rather because of it), "has not yet learned to make nothing" (Damian 1998, 365). For Anselm, similarly, neither has God, for all his omnipotent knowledge and loquacity, yet learned to think or speak nothing. Thus, while Anselm on the one hand clearly affirms that God could have created things other than those he did create (or even none at all), the truth of this does not require that 
On this reading of Anselm's general doctrine of God and creation in the Monologion, then, it is what God has actually made his creation to be in the divine locutio, now revealed to be the divine Son, that determines what is possible for his creatures to be. To come now to the second part of this article, it is broadly this same, theistic actualism that is likewise implied in Anselm's more specific teaching on the actual person and work of the divine Son in human history. In his most important and influential Christological work, Cur Deus Homo, or "Why the GodMan?", Anselm makes his case for the rational necessity of the Incarnation and Atonement of Christ in order to secure human salvation. As I have argued elsewhere, paralleling his views on God's possibilities for creation, Anselm views the necessity of the Incarnation as neither a necessity preceding and so determining from before the fact God's action, nor as the logical and metaphysical consequence of God having previously chosen and implemented one possible plan of creation and redemption when there were other possibilities he might have chosen instead. Rather, just as it is what God has actually made creation to be that subsequently and yet absolutely determines what is possible for him to do or make within his creation, so it is what God has done at an earlier moment within time that determines the necessity, including the necessity of the Incarnation, of what God does at a later moment, for in God's eternity, of course, what are otherwise two temporally removed and distinct effects nevertheless have a single, integrally unified divine cause and activity. In this sense, God is not only the creator of his own possibility, but also the creator of his own necessity. ${ }^{15}$

Our interest here, however, is not in Anselm's argument for the necessity of the Incarnation per se as it is in his teaching on the possibility and possibilities of the Incarnate Son himself. In the person of Boso, his interlocutor in the dialogue and real-life student and friend, Anselm raises a number of objections concerning the doctrine of the Incarnation, one of which is how God could have been just in commanding so good and innocent a man as Christ was to suffer and die (Cur Deus Homo 1.9). Here, it is worth noting, Anselm indirectly addresses a critique that has been levied in recent years against the whole tradition of penal substitutionary atonement, namely that its supposition of the divine Father pouring out his wrath on his own Son involves a horrendous case of divine and cosmic "child abuse."16 In contrast to this critique, what Anselm's response to Boso's question makes plain is

there be other, determinate yet unused possibilities just "there," waiting for God to actualize them whether he ever does so or not.

${ }^{15}$ On this reading Anselm's Cur Deus Homo, see McIntosh (2017a).

${ }^{16}$ For a discussion of Anselm in light of this modern objection to the doctrine of the atonement, see Weaver (2001, 191ff.). 
that Anselm is in fact far less interested in what God was demanding of-much less doing to-a putatively passive, suffering Christ, than he is interested in what Christ, on his own initiative (albeit under God's providence) elected to do on behalf of our fallen humanity and without any formal requirement from God that he do so. ${ }^{17}$ Thus, Anselm begins his response by denying that Christ's suffering and death were in fact commanded or required by the Father, at least so far as Christ's human nature and obedience were concerned. In his humanity, rather, what God required of Christ was nothing more nor less than what he requires of every human being, namely their complete obedience and rectitude of will. Since human suffering and death were only introduced into the world as a consequence of and punishment for sin, whereas Christ was perfectly obedient and hence sinless, God did not, and what is more, by his own established order could not require suffering and death as a condition of Christ's human obedience. ${ }^{18}$ In Anselm's words, "God did not compel Christ to die, for in Christ there was no sin. Instead, Christ willingly underwent death - not by obeying a command to give up His life but by obeying the command to keep justice. For He persevered so steadfastly in justice that He incurred death as a result." Christ's suffering and death, then, were not a formal condition or stipulated requirement of his obedience, but were merely the "accidental" (even if divinely ordained or planned) consequences of his living out a perfectly obedient and just life in the company of evil and unjust men. ${ }^{19}$ (To use the classic, Aristotelian distinction, Christ's obedience was not a "per se" cause but only a "per accidens" cause of his suffering and death.) Thus, while Christ's obedience did not necessitate his suffering and

\footnotetext{
${ }_{17}$ Weaver also acknowledges this point in his critique of the tradition of penal substitutionary atonement (Weaver 2001, 191-92).

${ }^{18}$ According to Deme, a consequence of God's not commanding Christ's suffering and death for our sins is that neither does Anselm ever think of Christ as undergoing punishment for our sins, meaning that Anselm's satisfaction theory of atonement is not strictly speaking a penal satisfaction view. See Deme (2003, 86-90). Similarly, John McIntyre writes of Anselm's treatment of the death of Christ that, "though emphasising the difficult and painful character of that Death, he does not regard it as a penal substitution... [T] he link between satisfaction and penance... is entirely absent from St. Anselm's conception" (McIntyre 1954, 87).

${ }^{19}$ As Anselm asks, "Why did the Jews persecute Him to the point of death?", to which Boso replies, "For no other reason than that He held unwaveringly to justice and truth in His deeds and words." Thus, while Anselm admittedly does not stress the point, I think Weaver is not quite correct when he says, not only that Anselm "delete[s] the devil from the atonement equation," but also that "Anselm did not directly address the issue of who was the author or the agent of the death of Jesus" (Weaver 2001, 200). As I suggest presently, Anselm's argument is effectively that Jesus's Jewish persecutors were the per se cause of his death, whereas the purpose of God and Christ were only the per accidens cause of it.
} 
death, Anselm's point is that, at the same time, it was his perfect obedience that, by happening to incite the jealousy, hatred, and violence of sinful men, led to his suffering and death. Without making them to be a necessary consequence of his obedience, then, Anselm's view is that Christ's obedience nevertheless did help make his suffering and death to be possible, and by making them possible, helped make possible man's salvation. Similar to the relationship between God's own action and possibilities, accordingly, Christ's suffering and death were not antecedent conditions, and in that sense prior "possibilities," for his obedience, but were instead possibilities created by him through the action of his obedience.

Although Christ's death may not have been a requirement for his human obedience, Anselm does acknowledge that, like any proper creaturely act of will, Christ's desire to lay down his life for man's salvation was nevertheless a gift he received from the same divine source from which his will to obey also came. In his words, Christ "could not have had the will by which He willed to die (in order to perform such a good deed) except from the Father of lights, from whom comes every best gift and every perfect gift" (1.10). Although the Father did not command Christ to suffer and die, accordingly, he did give him the created will to do so (and so in that limited sense may be said to have "willed" his suffering and death). As Anselm does not fail to remember, dying for man's salvation was, after all, the whole purpose behind God becoming man in the first place, and as Anselm argues in one of his earliest dialogues, On Truth (ch. 2), such prior purposes or intentions themselves can in their turn become their own source of obligation. Thus, we might say that even if Christ did not have the obligation to die as a man in general, Christ, of course, was no ordinary man, but is the Incarnate Son of God who only became man for the prior purpose and will of saving the human race, and so by this means was responsible for creating and so bequeathing to himself his own obligation to die as this particular man. ${ }^{20}$ Thus, the way in which God willed Christ's suffering and death was not as acts of obedience to a prior, standing command, yet neither should it be said (and as one critic has wrongly faulted Anselm for saying) that God therefore "wills Christ's Death after it takes place" (McIntyre 1954, 160). Rather, his point seems to be that God willed Christ's suffering and death precisely and exclusively through a unique and free act of Christ's own human and hence created will that went above and beyond those things God had otherwise commanded him, as a created man, to do.

${ }^{20} \mathrm{I}$ am indebted to Deme in helping me make this distinction when he writes that "In Anselm the purpose of this man's life is to die as God. And he does not leave any doubt about the point that the purpose of Christ's life is to die for sinners' sake" (Deme 2003, 214, emphasis original). 
One resulting irony of this discussion is that, notwithstanding his own, earlier account of freedom as the ability to preserve rectitude of will for its own sake (On Freedom of Choice 3), in Cur Deus Homo Anselm actually locates Christ's own greatest act of freedom in his performing an action that in fact exceeded the requirements of the mere rectitude of human will. ${ }^{21}$ Instead, while the requirements of Christ's human nature and the rectitude of will are what provided him with the necessary conditions for his sacrificial act, in its surpassing every such condition, his action did not realize an existing possibility of free will so much as it opened up and created-under God's own act of willing, once more-an entirely new, creaturely possibility of free action. Only in this way-as a free, uncoerced choice overreaching all moral duty or divine command-could Christ's suffering and death prove to be (as Anselm explains more fully later in Cur Deus Homo) a sufficient or suitable repayment of humankind's debt of sin, and so fulfill God's own uncommanded wish that the human race should be saved. As man fell by failing to act according to precisely those possibilities God had created for him, so it fell to the God-man to redeem man by "creating" for himself, as it were, an altogether new possibility of action that God had (until now) never created for any man.

Our next point for consideration in the modality of Anselm's Christology, and which follows upon his conclusion for the necessary fact of God's taking on human flesh for the satisfaction of human sin, concerns his argument for the particular manner in which God needed to take on human flesh. Here Anselm makes the highly significant claim that God could not assume it by creating an altogether new human being who was not in fact descended from Adam, for "then this human being would not belong to the human race that is born from Adam" (non pertinebit ad genus humanum quod natum est de Adam-2.8). To save the race of Adam, therefore, it was necessary that the God-man be born of the race of Adam, a thesis that, as we shall see presently, is as suggestive for what it may say about the possibility of being human as it is for what it says about the possibility of humans being saved. To begin, what Anselm is intending to deny here is simply that any "new man" (novum hominem) who is not a biological descendant of Adam can be of the "same race" (eiusdem generis) of Adam. As David Brown has rightly argued, "race" is the preferred translation for genus in this context, "inasmuch as Anselm claims that it would not even have been enough for Christ to have had the same 'nature': there must also have been a genetic connection" (Brown 2004, 287).

${ }^{21}$ Though as Deme is right to point out, "The first kind of obedience, is, of course, the presupposition of the second, yet in the final analysis we have to insist on the unity, or even identity, of the two" (Deme 2003, 195). 
Brown, however, I think goes beyond what the evidence warrants when he further infers from this that for Anselm someone could share in Adam's "nature" without also sharing in his "race." On the contrary, there are good, Anselmian and actualist reasons for thinking that one's genealogical connection with Adam is in fact, albeit paradoxically, a necessary condition for belonging even to the same nature or species as him. Earlier in Cur Deus Homo, for example, Anselm had made the claim that "human nature (humana natura) was present as a whole (tota erat) in our first parents," with the result that it was human nature that was likewise "conquered as a whole in them" as well (1.18). Taken at face value, this would seem to suggest that it was not merely all of his actual (or even possible) descendants that existed in Adam, but that it was the very nature and hence possibility of humanity as such that existed in him as well. If so, then the idea that there could be a human being who was not genealogically related to Adam would be nothing more than an empty fiction, and an ultimately incoherent one at that, and hence no true possibility at all. ${ }^{22}$ This interpretation, in any event, agrees well with our above, actualist reading of Anselm's doctrine of the divine locutio from the Monologion, according to which God sovereignly and creatively invents and speaks the very form or nature of man only as part of his express intention of bringing this particular, actual creation and its order into being. On the latter account of divine possibility, after all, God's "first" thought of man would not, ostensibly, have been of an abstract form or idea coeternal with God in the divine mind, as per Augustine's doctrine of the divine ideas. Rather, God's first (and only) thought of man would have been, at least so far as we know, that of Adam himself, along with all those who would, or at most possibly could, be descended from him. Adam, in other words, was no mere instance of an independently and previously existing Platonic type, but by God's original, creative intention and design, was the very type, meaning, and possibility of all that it means to be human, without remainder. ${ }^{23}$ And if genealogical descent from the actual person of Adam, finally,

${ }^{22}$ Thus, I think Deme does not quite go far enough when he says, for Anselm, "In theory, we could conceive of a human person created outside the corrupted line of Adam's children, created extra-cosmically and individually. Yet again, this person would not be the one who is in debt" (Deme 2003, 100). For Anselm, rather, not only would such a "person" be unable to repay Adam's debt, but such an individual would arguably not be human at all.

${ }^{23}$ I think neither Jasper Hopkins nor Brown are quite right, therefore, in their disagreement over whether, for Anselm, Christ assumed human nature in general or only the particular human nature of a concrete, individual man. On the one hand, Hopkins says that while "At times Anselm tends to regard human nature as if it were an unindividuated universal," in general his view is nevertheless to be set "in contrast with the position that the second person of the Trinity did not assume a particular human nature but human nature as a whole. Thus, as original man (Adam) was universal man, so the God-man (second Adam) was also universal man. As the whole human race 
is what constitutes, even for God, because by God's own inalterable purpose and design, the very possibility of being human, then it is also what makes possible the divine Son's Incarnation into the human race as the "second Adam."

In addition to the human side of the possibility of the Incarnation, Anselm also touches on its possibility from the divine side, when he argues for why, of the three persons of the Godhead, it was specifically the second person, the divine Son, for whom it was peculiarly fitting, necessary, and hence possible for God to become man in order to save the human race (2.9). Here, as above with the divine ideas, Anselm's significance may be best appreciated by briefly contrasting him with Augustine and the mainstream theological tradition stemming from him. Although Augustine gave his own reasons for why it was the Son who became Incarnate, he nevertheless stressed that whatever is done by one person of the Trinity is equally and equivalently done by the others (Jenson 2001, 111, citing Augustine, Epistle 11 and De trinitate 5.9). According to Robert Jenson, this led to what became virtually "an axiom for theology" in subsequent Christian thinking on the topic, namely the thesis that it was at least possible for the Father or the Spirit to have become incarnate as well, a view held, for example, by such eminent and influential medieval thinkers as Peter Lombard and Thomas Aquinas (Jenson 2001, 111-12). ${ }^{24}$ In this manner, it might be said, an uncreated, generic possibility-of-

was present in Adam, so Adamic human nature as a whole was present in Jesus... In refusing to contemplate this position Anselm teaches that the Son of God united Himself with $a$ human nature rather than with human nature as such. Therefore, the incarnate Word was a man and not Man. Accordingly, the title Cur Deus Homo should be interpreted (not translated) as Why God in the person of the Son assumed a human nature" (Hopkins 1972, 196 and 201). On the other hand, Brown, interpreting Anselm's teaching here in light of Augustine's Platonic doctrine of divine ideas (wrongly, as I showed earlier), says that the atonement is "secured through us 'participating' in the perfect exemplar or 'universal' human nature that Christ came to offer" (Brown 2004, 288-9). He goes on to imply that Anselm was in some ways in sympathy with the doctrine of anhypostasia, alluded to above by Hopkins as a way of setting in contrast Anselm's own view, according to which "in the Incarnation God assumed an impersonal human nature, not the characteristics that would make Him a distinct human personality" (289). The present, actualist reading of Anselm's view of the humanity of Adam and Christ, by comparison, lands somewhere between these two views: that he thinks of their human nature as neither a Platonic archetype, nor as a privileged, historical instance or instantiation of such an archetype, but as something closer to what we might call an "individuated universal" (to adapt Hopkins's terminology) or a "concrete universal" (as McIntyre $(1954,123)$ has referred to him); that is to say, they were men who simultaneously had a human nature and who, as the heads of their respective "descendants" (genealogical for Adam, spiritual for Christ) also were the whole of their human nature.

${ }^{24}$ Regarding Lombard, Jenson cites his Book of Sentences 3.1.3. And in his commentary on the latter passage, Aquinas, too, allows for the possibility of the Father or the Spirit having become incarnate as well (Moonan 1994, 292). The problem with this “Augustinian supposition," in Jenson's 
Incarnation in the abstract was predicated of the Godhead in general, a possibility that was non-specific to, and so might be understood as existing independently of, any one person of the Trinity, and therefore able to be indifferently realizable by any one of them. ${ }^{25}$ And although Anselm, too, has been interpreted in a similar light (see e.g. McIntyre 1954, 136), Anselm himself, on the contrary, makes a case, in Cur Deus Homo 2.9, for the unique fittingness of the Son being the divine person to become incarnate, and what is more, that this fittingness is actually indicative of an even deeper necessity. As he states matters in the title of the chapter, "It is necessary (quod necesse sit) that the Word alone and a human nature conjoin in one person." For Anselm, it was the Son who became incarnate for man's salvation because at some level it was the Son who must become incarnate for man's salvation. One of the principal arguments Anselm gives for this conclusion is that "it sounds more fitting for the Son to supplicate the Father than for another of the persons to supplicate either of the other two" (2.9). Unfortunately Anselm doesn't elaborate on this claim of the superior fittingness of the Son's Incarnation, yet this much is at least made clear: for Anselm, there is something in the Son's eternal, ontological, and ad intra identity as the Son, and specifically as he relates to the Father, prior to and apart from the actual fact of the Incarnation, that in some sense uniquely qualifies him for the supplicatory role that the God-man would have to fill-and which Christians now know him to have in fact filled-with respect to God. If so, then it is possible to discern in Anselm's argument for the fittingness of the Son's Incarnation a concern to draw a closer connection between the Son's peculiar relation to the Father on the one hand and his peculiar role in redeeming man on the other. ${ }^{26}$ In sum, it is who the Son eternally and actually is, as the second

view, is that in it "there is no necessary connection between what differentiates the triune identities in God and the structure of God's work in time," with the result that it "bankrupts the doctrine of Trinity cognitively, for it detaches language about the triune identities from the only thing that made such language meaningful in the first place: the biblical narrative" (Jenson 2001, 112). Put in different terms, it is the theistic possibilist presumption that one may abstract our knowledge of what is possible for the persons of the Trinity from the concrete, historical-redemptive actions through which those persons have actually been revealed and made known to us.

${ }^{25}$ Over against this Augustinian legacy, Jenson commends instead the counter-testimony of what he identifies as the "authentically Nicene analysis" of John of Damascus (ca. 675-749), who writes that "It was the Son of God who became the son of man, so that his individuating property might be preserved. As he is Son of God he became a son of man..." John of Damascus, Expositio fidei 77.5-8, cited in Jenson $(2001,112)$. On this alternate account, it would seem, it is who the Son eternally, uniquely, and actually is that determines for him the possibility of his Incarnation.

${ }^{26}$ As Deme again aptly puts it, "What happens between the Father and the Son is the true mirror of the Father's or God's relation to his creature," such that "For Anselm's theology, the way in which God relates to himself in his Son, is the spring of his actions and decisions towards man." (Deme 
person of the Trinity, and so who and what God is through him, that not only makes possible God's creation of the world through his Word, but consequent to this, is also the very possibility of his entering that same creation to redeem it.

Much more might and deserves to be said on Anselm's account of divine possibility and its simultaneous Christological basis and application, yet the foregoing I trust has given a sufficient introduction to how the divine Son serves as an integral even if implicit part of how Anselm would have us understand all that God can do. Through the eternal Son, God has not so much realized already existing possibilities that are co-eternal with himself, existing or thought of by God prior to and independent of what he actually does, as per the divine ideas tradition, so much as he has creatively and inventively spoken-ex nihilo, de novo, and $a d$ hoc-his own possibilities into existence. One of those principal possibilities devised in the eternal Son, moreover, and as it turns out, is God's own ability to Incarnate himself $a s$ one of his own creaturely possibilities. Through God's action and, more specifically, obedience as one of his own creatures, moreover, Anselm further represents God as continuing to create new possibilities of action not strictly speaking contained within the preceding state of affairs, nature of things, or commands of God. In this way, the divine Son is revealed as no mere instrumental means whereby God is able to realize divine possibilities otherwise conceived or conceivable on some other, independent or non-Christological but philosophical and in that sense "secular" grounds, but instead as the irreducible source of every divine possibility, in its very possibility. If so, then I think Anselm may be seen to take us a long way towards satisfying what might be identified as a permanent task within Christian theology, namely what John Milbank has described as the necessity that divine omnipotence should be fully "inscribed within the form of

2003, 122, emphasis added). Later, Deme speaks again of how, for Anselm, "Satisfaction is possible when the Son, who is the true image of the Father, takes upon himself the true image of man, and in one person pays what man owes but only God can pay. The Son is the blueprint of humanity from eternity (and by saying this I take the liberty of saying slightly more than Anselm did)... We can say that the possibility of the satisfaction, which is indispensable for the restoration of the order in the universe and that of God's honour, is the actuality of the perfect conjunction between the image of God in which man was created with its creaturely form. Thus, what is necessary in God is possible in Christ" $(2003,96)$. Finally, in a passage now commenting specifically on Anselm's above argument for the Son's peculiar suitability for assuming human nature, what Deme says we have here is nothing less than "the incarnational extension of [Anselm's] doctrine of the Father and the Son... The incarnation of the Son involves a begetting and a birth, which are an integral part of sonship in general... The capacity to become man and to be incarnated, with all that follows from this, pertains therefore exclusively to the Son... From this is clear that the inner, essential divine order that is a constitutive element of God's being ad intra will be explicitly reflected in his dealing with humanity through Jesus Christ" (2003,138, emphasis added). 
Christ's life and the Christ-formed world" (Milbank 1997, 23). Or, in the words of the Apostle Paul with which we began, that Christ should be understood, loved, and worshipped as the very "wisdom and power of God."

\section{Bibliography}

Anselm. 1946. Opera Omnia. Edited by F. S. Schmitt. Edinburgh: Thomas Nelson and Sons.

Anselm. 2000. Complete Philosophical and Theological Treatises of Anselm of Canterbury. Translated by Jasper Hopkins and Herbert Richardson. Minneapolis, MN: The Arthur J. Banning Press.

Brown, David. 2004. "Anselm on Atonement." In The Cambridge Companion to Anselm, edited by Brian Davies and Brian Leftow, 279-302. Cambridge: Cambridge University Press. https://doi.org/10.1017/CCOL0521807468.013.

Courtenay, William. 1975. "Necessity and Freedom in Anselm's Conception of God." Analecta Anselmiana 4 (2): 39-64.

Courtenay, William. 1990. Capacity and Volition: A History of the Distinction of Absolute and Ordained Power. Bergamo: Lubrina.

Damian, Peter. 1998. The Letters of Peter Damian, 91-120. Translated by Owen J. Blum. Washington, D.C.: Catholic University of America Press.

Deme, Dániel. 2003. The Christology of Anselm of Canterbury. Aldershot: Ashgate.

Evans, G.R. 1978. Anselm on Talking About God. Oxford: Clarendon Press.

Hopkins, Jasper. 1972. A Companion to the Study of St. Anselm. Minneapolis, MN: University of Minnesota Press.

Jenson, Robert. 2001. Systematic Theology: Volume 1, Triune God. Oxford: Oxford University Press.

Jordan, Mark. 1984. "The Intelligibility of the World and the Divine Ideas in Aquinas." Review of Metaphysics 38 (1): 17-32.

Knuuttila, Simo. 1993. Modalities in Medieval Philosophy. London: Routledge.

Knuuttila, Simo. 2004. "Anselm on Modality." In The Cambridge Companion to Anselm, edited by Brian Davies and Brian Leftow, 111-31. Cambridge: Cambridge University Press. https://doi.org/10.1017/CCOL0521807468.006.

Leftow, Brian. 1995. "Anselm on the Necessity of the Incarnation." Religious Studies 31 (2): 167-85. https://doi.org/10.1017/S0034412500023477.

Leftow, Brian. 2012. God and Necessity. Oxford: Oxford University Press. https://doi.org/10.1093/acprof:oso/9780199263356.001.0001.

Mann, William. 2004. "Anselm on the Trinity." In The Cambridge Companion to Anselm, edited by Brian Davies and Brian Leftow, 257-78. Cambridge: Cambridge University Press. https://doi.org/10.1017/CCOL0521807468.012. 
McIntosh, Jonathan. 2017a. "God, Creator of His Own Necessity: The Logic of Divine Action in Anselm's Cur Deus Homo." The Saint Anselm Journal 13 (1): 6881.

McIntosh, Jonathan. 2017b. "Speaking of Possibilities: The Theistic Actualism of Anselm's Divine Locutio." Modern Theology, 33 (2): 213-34. https://doi.org/10.1111/moth.12311.

McIntyre, John. 1954. St. Anselm and His Critics: A Re-Interpretation of the Cur Deus Homo. Edinburgh: Oliver and Boyd.

Milbank, John. Word Made Strange: Theology, Language, Culture. Oxford: WileyBlackwell, 1997.

Moonan, Lawrence. 1994. Divine Power: The Medieval Power Distinction up to its Adoption by Albert, Bonaventure, and Aquinas. Oxford: Clarendon Press, 1994. https://doi.org/10.1093/acprof:oso/9780198267553.001.0001.

Rogers, Katherin. 1997. The Neoplatonic Metaphysics and Epistemology of Anselm of Canterbury. Lewiston, NY: Edwin Mellen Press.

Rogers, Katherin. 2003. "Anselm on God's Perfect Freedom." The Saint Anselm Journal 1 (1): 1-8.

Rogers, Katherin. 2008. Anselm on Freedom. Oxford: Oxford University Press. https://doi.org/10.1093/acprof:oso/9780199231676.001.0001.

Rogers, Katherin. 2009. “Back to Eternalism: A Response to Leftow's 'Anselmian Presentism'." Faith and Philosophy 26 (3): 320-38. https://doi.org/10.5840/faithphil200926317.

Ross, James. 1986. "God, Creator of Kinds and Possibilities: Requiescant universalia ante res." In Rationality, Religious Belief, and Moral Commitment: New Essays in the Philosophy of Religion, edited by Robert Audi and William J. Wainwright, 315-34. Ithaca, NY: Cornell University Press.

Ross, James. 1990. "Aquinas's Exemplarism; Aquinas's Voluntarims." American Catholic Philosophical Quarterly $64 \quad$ (2): $171-98$. https://doi.org/10.5840/acpq199064234.

Shimizu, Tetsuro. 2006. "Word and Esse in Anselm and Abelard." In Anselm and Abelard: Investigations and Juxtapositions, edited by Helmut Kohlenberger and Giles E. M. Gasper, 179-95. Toronto: Pontifical Institute of Mediaeval Studies.

Vanderjagt, Arjo. 1999. "Propter utilitatem et rationis pulchritudinem amabilis." In Cur Deus Homo: Atti del Congresso Anselmiano Internazionale, edited by Paul Gilbert, Helmut Karl Kohlenberger, and Elmar Salmann, 717-30. Rome: Centro studi S. Anselmiana.

Visser, Sandra and Thomas Williams. 2009. Anselm. Oxford: Oxford University Press. 
CHRIST, THE POWER AND POSSIBILITY OF GOD

Weaver, J. Denny. 2001. The Nonviolent Atonement. Grand Rapids, MI: Eerdmans.

Published Online: December 12, 2018 